\title{
Food and Non-Food Consumption Expenditure In Medan City and Its Affecting Factors (Case Study of Java and Batak Tribes)
}

\author{
Jana Putri Utami, SP1, MP, Sri Fajar Ayu, SP, MM, DBA ${ }^{2}$ \\ Alumni Master of Agribusiness Faculty of Agriculture Universitas Sumatera Utara ${ }^{1}$ \\ Lecturer in Agribusiness Master's Degree, Faculty of Agriculture, Uiversitas Sumatera Utara ${ }^{2}$ \\ Prof. A. Sofyan Street, Number $3^{\text {rd }}$, Medan \\ Email: agribisnisjanaputri@gmail.com
}

\begin{abstract}
Household consumption expenditure is the value of expenditure made by households to purchase various types of needs (food and non-food) within a certain period of time. Based on BPS's data of Medan City Year 2016, the biggest expenditure on non food. With the growing number of people every year, and the more diverse the tribe in Medan City, the more diverse consumption of households in the city of Medan. This research was conducted to analyze the expenditure of food and non-food household consumption in Medan City and the factors that influence it. Factors affecting consumption are behavior, economy, social environment as well as food and non-food stock factors. Determination of location is done purposively (purposive) that is in Medan City with case study choose two biggest tribe in Medan City, that is Java and Batak. Sampling is done by Slovin Method, which is 100 household samples consisting of 62 Javanese and 38 Batak tribe households. The data collected are primary and secondary data. Primary data obtained from questionnaires and secondary data obtained from relevant agencies such as BPS Medan City. Research problem solving using descriptive method and multiple linear regression method. The results of this research are (1) consumption expenditure of Java is dominated by non-food expenditure, namely clothing, footwear, and head covering because they prepare the needs of Idul Fitri holidays. While the Batak tribe is dominated by food expenditure. (2) Factors influencing food consumption expenditure The Javanese is the income factor, while the factors that influence food consumption expenditure of Batak Tribe are consumptive lifestyle factors of food, income and age. (3) Factors affecting non-food consumption expenditure The Javanese is income factor, while the factors affecting non-food consumption expenditure Batak Tribe is the factor of the number of household members.
\end{abstract}

Keywords : household consumption, behavioral factors, economy, social environment, food and non-food stock

\section{PRELIMINARY}

According to Samuelson and Nordhaus (1995) defining that household consumption is the expenditure for the purchase of final goods and services in order to obtain satisfaction or fulfill their needs. Households that have high incomes will do a high consumption also and low-income households will perform low consumption as well.

The number of population that many make more variation factor of household consumption variable to be studied in Medan City. Medan city has 21 subdistricts. As one of the autonomous regions with city status, the position, function and role of Medan City is quite important and strategic both regionally and nationally. Even as the capital of North Sumatra Province, Medan City is often used as a barometer and benchmark in the development and implementation of local government.
With the increase of population in every year, hence also increasing requirement of household consumption. As is the case in Medan City in 2016, based on BPS data of 2016, food / food expenditures amounted to 532,642 capita / month or equivalent to $46.09 \%$, while for non-food items expenditure of 623,106 capita / month or equivalent with 53.91\%. Thus overall in 2016, household consumption in Medan City is dominated by non-food ingredients.

The diversity of the population of Medan City that so much causes the city of Medan to become a city rich in various ethnic cultures. Based on the population census in 2010, the dominant tribe in Medan City is the Javanese (30.57\%), Batak $(18.54 \%)$ and the rest is filled by other tribes.

The cultural diversity of the various tribes is a highly valued heritage. Behavior of eating or non-eating activities is also an important part of customs in various tribes, some even become 
cultural symbols and potentially a part of national culture.

Therefore, this research is very important to analyze how the expenditure of food and non food consumption of household is based on Javanese and Batak tribe in Medan City. And analyze what factors affect the consumption expenditure of food and non-food households of the Javanese and Batak tribes in the city of Medan.

Based on the above description, then the issues to be discussed in this study are as follows:

1. How does the food and non-food consumption expenditure of Javanese and Batak households in Medan City?

2. Are the behavioral factors (consumptive lifestyles), economy (income), social environment (age of head of household, education, number of household members and customs), and food stock factors affect the consumption expenditure of Javanese and Batak household households in Medan city?

3. Are the behavioral factors (consumptive lifestyles), economy (income), social environment (age of head of household, education, number of household members and customs), and non-food stock factors affect nonfood consumption expenditure of Javanese households and Batak in Medan City

\section{BASIS OF THEORY}

Theories used in this study is the theory of Consumption. Consumption is a function of revenue that can be spent. The income of the family or the incoming money is mostly spent again, to buy the necessary to live. In economics it is said: spent for consumption. Consumption is not just about food, but includes the use of goods and services to meet the needs of life (Gilarso, 1992).

Engel's theory states that low-income households will spend most of their income on basic food (food). On the other hand, high-income households will spend only a fraction of the total demand for basic needs (food). There are three factors that influence consumer behavior are:

1. The influence of the environment, consisting of culture, social class, family and situation.

2. Individual differences and influences, consisting of motivation and involvement, knowledge, attitude, personality, lifestyle, and demography.
3. Psychological process, consisting of information processing, learning, attitude and behavior change (Nicholson, 2001).

Consumption by Mankiw (2006) "Consumption is goods or services purchased by household consumption consisting of non durable goods (Non Durable Goods) are goods that are used up in a short time, such as food and clothing, the second is durable goods (Durable Goods) are goods owned by longevity such as cars, televisions, electronic appliances, Third is services (Services) include work done for consumers by individuals and companies such as haircuts and medical treatment to the doctor.

The level of consumption of a person or household is determined by his income. Keynes divides into two most important parts, namely: Factor Objective, which is a factor that is generally recognized as a factor that affects consumption. Factor Objective is divided into 3 namely: price, fiscal policy and interest rate. And Subjective Factors, ie factors that come from the conditions experienced by everyone. Subjective factors do not always have the same effect on everyone. Subjective factors are divided into 2, namely: caution and wealth (inheritance) owned (Huda, 2012).

The theory with a permanent income hypothesis is proposed by M Friedman. According to this theory people's income can be classified into 2, namely permanent income (permanent income) and transitory income (transitory income). The notion of permanent income is income that is always received in any given period and can be predicted before, such as income from salary, wages. Income derived from all factors that determine a person's wealth (which creates wealth). The notion of temporary income is an unpredictable income (Mangkoesoebroto, 2001).

The theory with the life cycle hypothesis is exposed by Franco Modigliani. Franco Modigliani explains that the pattern of public consumption expenditure is based on the fact that the pattern of income and consumption patterns of a person is generally influenced by the period in his life cycle. Because people tend to receive low income / income at a young age, high in middle and low age at old age, then the savings ratio will fluctuate in line with their age progression ie young people will have a negative savings (dissaving), middle-aged people save and pay return the loan in their youth, 
and the elderly will take the savings he made in his middle age. Furthermore Modigliani considers important role of wealth (assets) as a determinant of consumption behavior. Consumption will increase if there is an increase in the value of wealth, such as due to inflation, the value of the house and land increases, due to an increase in the price of securities, or due to an increase in the money supply. Indeed, in reality people accumulate wealth throughout their lives, and not just people who have retired. If there is an increase in the value of wealth, then consumption will increase or can be maintained longer. Finally, the hypothesis of this cycle of life would mean suppressing the desire for consumption, suppressing the coefficient of multipliers, and protecting the economy from unexpected changes, such as changes in investment, exports, and other expenditures (Suparmoko, 1991).

James Dusenberry argues that the consumption expenditure of a society is determined primarily by the highest income ever achieved. Revenue is reduced, consumers will not reduce much of their spending on consumption. To maintain a high level of consumption, forced to reduce the amount of saving. If the income increases then their consumption will also increase, but the increase is not too large. While saving will grow big by rapidly. This fact continues to meet until the highest level of income we have achieved is achieved again. After the peak of the previous income has been passed, then the additional income will lead to increased spending for consumption, while on the other side increased saving is not so fast (Reksoprayitno, 2000).

According to Kotler and Keller (2012) consumers make their decisions not in a place that is isolated from the surrounding environment. Their buying behavior is strongly influenced by cultural, social, personal, and psychological factors. And from personal factors there are consumer lifestyle factors that influence his decision in buying a product. Kotler and Keller put forward the following definition of lifestyle: "Lifestyle is the lifestyle of a person in a world expressed in activity, interests, and opinions. Lifestyle describes the whole person in interacting with his environment. Lifestyle describes the whole pattern of a person in action and interact in the world ".

\section{RESEARCH METHODS}

\section{Location Determination Method}

The research area is determined purposively in Medan City, considering that in Medan city is one of the biggest cities in Indonesia that automatically there are consumer of Batak ethnic household and quite many people in Java tribe located in Medan City.

\section{Sample Determination Method}

The method of determining the sample is the process of selecting a certain number of individuals (samples) for a study, so that the individuals are representative of larger groups (population). In this study, the population is the sum of all food consumers and non-food households with Java and Batak ethnic in Medan City. While the sample is representative of the population (consumers of ethnic households of Java and Batak) which will be the object of research. The method of determining the number of food and non-food consumer sample of Javanese and Batak households in Medan City is done by Slovin method with the formula:

$$
\mathrm{n}=\frac{N}{1+N e^{2}}
$$

are :

$\mathrm{n}$ : Number of Samples

$\mathrm{N}$ : Total Population

e : Limit Tolerance Error (error tolerance)

The total population in this study is the total number of Javanese and Batak tribal households in Medan City as many as 251,205 Households of Java and Batak tribes. With a fault tolerance limit of $10 \%$, the sample size is 100 household samples, consisting of 62 Javanese and 38 Batak tribe households in Medan City.

Sampling method is Cluster Sampling (Sample Group). This method is used because the research object or research area is so wide that the population needs to be divided into several groups, then the sample will be randomly selected from each group such as the population of a country, province or district (Sugiono, 2012).

\section{Method of Collecting Data}

Data used in this research are primary data and secondary data. Primary data is data obtained through field surveys by using certain data 
retrieval methods. While the secondary data is data that has been collected by data collection agencies and published to the public data users.

Secondary data is obtained from related institutions. In this case the Central Bureau of Statistics (BPS) Medan City. While primary data come from field survey, observation and direct interview to household consumer in Medan City by using questionnaire. Interviews are the process of obtaining information for the purpose of research by means of question and answer while face to face between the questioner or the interviewer with the answering or respondent using a tool called interview guide (Nazir, 2005).

\section{Data Analysis Method}

The method of data analysis used in the first problem solving is descriptive method. Moh. Nazir (2005) states that descriptive method to examine the status of human groups, an object, a set of conditions, a system of thought, or a class of events in the present. The objective is to make a systematic, factual and accurate description, description, or painting of facts, traits and relationships between the phenomena investigated. In this case the descriptive method is used to analyze the consumption expenditure of Javanese and Batak households in Medan City. In this case the coverage of foodstuffs is food consumed daily, whereas non food consists of consumption outside of food consumed and needed in one month. And the method of data analysis for the second and third problem is to use Multiple Regression Analysis Method (multiple regression), where this method is used to know influence between some independent variable to dependent variable.

In the second problem, the independent variables consist of behavior (food consumptive lifestyles), economy (income), social environment (age of head of household, education, number of household members and customs) and food stock. While the dependent variable is household food expenditure of Java and Batak Tribe.

And on the third issue, the independent variables are behavior (non-food consumption lifestyle), economy (income), social environment (age of head of household, education, number of household members and customs) and non-food stock. While the dependent variable is non-food household expenditure of Java and Batak Tribe. The model specifications are as follows:
$Y=\beta 0+\beta 1 X 1+\beta 2 X 2+\beta 3 X 3+\beta 4 X 4+\beta 5 X 5+$ $\beta 6 \mathrm{X} 6+\beta 7 \mathrm{X} 7+\mu$

are :

$\beta 0=$ constants $/$ intercept

$\beta 0, \beta 1, \beta 2, \beta 3, \beta 4, \beta 5, \beta 6, \beta 7=$ value of each variable / regression coefficient

$\mu=$ error term (Coefficient Error)

Y1 = Household Food Consumption Expenditure of Java Tribe (Rupiah / Month)

Y2 = Spending on Household Consumption of Batak Tribe (Rupiah / Month)

$\mathrm{X} 1=$ Behavior (Consumtive lifestyle of Food)

(Rupiah / Month)

X2 = Revenue (Rupiah / Month)

X3 = Age of Household Head (Year)

$\mathrm{X} 4$ = Education (Year)

X5 = Number of Household Members (Soul)

X6 = Customs / Culture (Drinking Herbal) (Rupiah

/ Month)

X7 = Food stock (Rupiah / Month)

And

Y3 = Non-Food Household Consumption Spending on Java (Rupiah / Month)

Y4 = Non-Food Household Consumption Spending on Batak Tribe (Rupiah / Month)

$\mathrm{X} 1$ = Behavior (Non-Food Consumptive Lifestyle)

(Rupiah / Month)

X2 = Revenue (Rupiah / Month)

X3 = Age of Household Head (Year)

$\mathrm{X} 4$ = Education (Year)

X5 = Number of Household Members (Soul)

X6 = Customs / Culture (Eat Betel and Drink Tuak)

(Rupiah / Month)

X7 = Non-food stock (Rupiah / Month)

\section{Operational Definition of Variables}

The definition of operational variables is a limitation in explaining the variables used in the study, so that it is focused on the subject matter to be studied. In this study using some limitations of variables, namely:

a) Household Consumers are people who consume food and non food in one household.

b) Household Consumption Expenditure is expenditure for the purchase of final goods and services in order to obtain satisfaction or fulfill their needs measured in Rupiah per month.

c) Behavior (consumptive lifestyle) is the act of 
buying goods that are less or not taken into account so that the nature becomes excessive measured in units of Rupiah / Month.

d) Revenue (Rupiah / Month) is the result obtained from all members of the household either from the head of the family or the whole family.

e) Age of head of household (Year) is the life time that has been passed by tanngga house member which is calculated from birth year.

f) Education (Years) is a regular, systematic, multilevel, school-based education that follows clear requirements.

g) Number of Household Members (Soul) is the total of members consisting of husbands, wives, children, parents, in-laws and others living in one house.

h) Customs Istiadat is a standard rule of the ancestors according to the culture of each individual measured in units of Rupiah / Month. In this case the Javanese Drinking Herbal Tribe while the Batak Tribe Eat Sirih and Drink Tuak.

i) Household food and non-food stocks are sufficient food and non-food stock available in a household calculated in Rupiah / Month.

\section{DISCUSSION RESULT}

Food and Non-Food Consumption Spending of Java and Batak Tribe in Medan City

To analyze food and non-food consumption expenditure of Javanese and Batak tribe in Medan City can be seen in the following table:

Food and Non-Food Consumption Spending of Java and Batak Tribe in Medan City

\begin{tabular}{|c|c|c|c|c|c|}
\hline \multirow[b]{2}{*}{$\begin{array}{l}\text { SA } \\
\text { MP } \\
\text { LE } \\
62\end{array}$} & \multicolumn{2}{|c|}{ JAWA } & \multirow[b]{2}{*}{$\begin{array}{l}\text { SAM } \\
\text { PLE } \\
38\end{array}$} & \multicolumn{2}{|c|}{ BATAK } \\
\hline & $\begin{array}{l}\text { Food } \\
\text { Expe } \\
\text { nditu } \\
\text { re } \\
\text { (Rupi } \\
\text { ah/M } \\
\text { onth) }\end{array}$ & $\begin{array}{l}\text { Non- } \\
\text { Food } \\
\text { Expendit } \\
\text { ure } \\
\text { (Rupiah/ } \\
\text { Month) }\end{array}$ & & $\begin{array}{c}\text { Food } \\
\text { Expen } \\
\text { diture } \\
\text { (Rupia } \\
\text { h/Mon } \\
\text { th) }\end{array}$ & $\begin{array}{c}\text { Non- } \\
\text { Food } \\
\text { Expendi } \\
\text { ture } \\
\text { (Rupiah } \\
\text { /Month } \\
\text { ) }\end{array}$ \\
\hline $\begin{array}{c}\text { Tot } \\
\text { al }\end{array}$ & $\begin{array}{l}92,66 \\
2,300\end{array}$ & $\begin{array}{r}118,177,0 \\
00 \\
\end{array}$ & $\begin{array}{c}\text { Tota } \\
\text { l }\end{array}$ & $\begin{array}{r}59,440 \\
950 \\
\end{array}$ & $\begin{array}{r}59,418,5 \\
00 \\
\end{array}$ \\
\hline $\begin{array}{c}\text { Ave } \\
\text { rag } \\
\mathrm{e}\end{array}$ & $\begin{array}{r}1,494 \\
553\end{array}$ & $1,906,081$ & $\begin{array}{l}\text { Ave } \\
\text { rage }\end{array}$ & $\begin{array}{r}1,564,2 \\
36\end{array}$ & $\begin{array}{r}1,563,64 \\
5\end{array}$ \\
\hline
\end{tabular}

Source: Primary Data 2017, processed

Based on the above table, it can be seen that the consumption expenditure of Java Tribe in
Medan City is dominated by non-food consumption expenditure, which is $\mathrm{Rp} 118,177,000$ / month with a total sample of 62 heads of households in Medan City or with an average per head of the family of $\mathrm{Rp} 1.906 .081$ / Month. While Batak consumption expenditure in Medan City is dominated by food consumption expenditure, which is equal to Rp 59.440.950 / Month with total sample of 38 head of household in Medan city or with average per head of family Rp 1,564,236 / month.

The Javanese are more dominated by nonfood expenditure because in the month of this study, the average non-food consumption expenditure is increasing, they prepare the necessities of the holidays, such as clothes and so on. While Batak tribe is more dominated in food expenditure, because they spend their income not for non food consumption, so non-food expenditure can be minimized, and food expenditure remain as usual. In general, Batak tribe has a principle, anything will be done, as long as it is lawful. Nothing else is not merely to earn income to meet the needs of his life. And they eat a lot, with reason to be healthy (Nainggolan, 2015).

This is in line with Engel's law which states that low-income households will spend most of their income to consume basic needs (food). While high-income households will only spend a small portion of their basic needs (food) and the rest they use for other purposes outside of food and saving. Engel's law is in accordance with the results of research which states that the average household income of the Java Tribe of Rp 5,889,306 while the average household income of the Batak tribe of Rp 5,836,842. Therefore, Batak tribe more dominates the expenditure of food, while the Java Tribe dominate non-food expenditure (Nicholson, 2001).

Based on the results of the research, the largest type of household food expenditure of Java Tribe in Medan city based on the order is animal food, paddy rice, others, vegetables and fruits, sugar group, oil and fat, nuts, oily fruits and tubers -bugs.

Based on research results, the largest type of household food expenditure of Batak tribe in Medan city based on the order is animal food, paddy rice, others, vegetables and fruits, oils and fats, sugar group, tubers, oily fruits and nuts -help.

Different types of food expenditure The Javanese tribe is more likely to consume groups of 
sugar and beans. While the Batak tribe consume more oil and fat and tubers.

Equality of food expenditure Java and Batak is the largest expenditure on animal food and grains.

Based on the results of the study, the largest types of household non-food household expenditures on Java under the order are expenditures for clothing, footwear and head coverings, other expenses, expenses of various goods and services, payment of usage taxes and insurance premiums, housing expenditures and household facilities, the release of durable goods, and the expenditure of party and ceremonial purposes.

Based on the results of the research, the largest types of non-food household expenditures of Batak tribe are based on the order in which they are used for other purposes, housing and household expenses, party and ceremonial expenses, clothing, footwear and head cover, payment of usage tax and insurance premium, the expenditure of various goods and services, and the release of durable goods.

In non-food expenditure more dominant is the difference in customs. For the Java Tribe at the time of the research has never spent his income for the purposes of the party and the ceremony, because it is running fasting and preparation to welcome Idul Fitri holidays. While the Batak tribe quite a lot of use of income for the purposes of the party and ceremony.

\section{Factors Affecting Household Food Consumption Expenditure of Java Tribe in Medan City}

\section{Classic assumption test :}

Before the regression test to determine the factors that affect the consumption of household food expenditure Java Tribe in the city of Medan, first done Classic Assumption Test. The test that was made was Normality Test, Multicolinality Test, Autocorrelation Test, and Heteroscedasticity Test.

Normality test is used to detect whether the distribution of independent and bounded variables is normal. If $\operatorname{sig} \geq \alpha$ Then $\mathrm{HO}$ is accepted, $\mathrm{H} 1$ is rejected. The samples are normally distributed ( $\mathrm{Sig}=0.965>\alpha=0.05(5 \%)$ ).
One-Sample Kolmogorov-Smirnov Test

\begin{tabular}{|c|c|c|}
\hline & & $\begin{array}{l}\text { Unstandardized } \\
\text { Residual }\end{array}$ \\
\hline \multicolumn{2}{|l|}{$\mathrm{N}$} & 62 \\
\hline \multirow[t]{2}{*}{ Normal Parameters ${ }^{a}$} & Mean & .0000000 \\
\hline & $\begin{array}{l}\text { Std. } \\
\text { Deviation }\end{array}$ & $3.30342296 \mathrm{E} 5$ \\
\hline \multirow{3}{*}{$\begin{array}{l}\text { Most Extreme } \\
\text { Differences }\end{array}$} & Absolute & .063 \\
\hline & Positive & .063 \\
\hline & Negative & -.047 \\
\hline \multicolumn{2}{|l|}{ Kolmogorov-Smirnov Z } & .499 \\
\hline \multicolumn{2}{|l|}{ Asymp. Sig. (2-tailed) } & .965 \\
\hline $\begin{array}{l}\text { a. Test distribut } \\
\text { Normal. }\end{array}$ & & \\
\hline
\end{tabular}

Multicolinearity test (tolerance> 0.1 and VIF <10) was used to test whether the regression model found a correlation between independent variables. Based on the result of research, all variables have tolerance value $>0.1$ and VIF $<10$. Based on these criteria, the regression model is good because there is no correlation between the independent variables (Consumtive Lifestyle (food), Income, Age, Education, Number of Household Members, Traditional Drinking), and Food Stock.

\begin{tabular}{|r|r|r|}
\hline & & \multicolumn{2}{|c|}{ Collinearity Statistics } \\
\cline { 2 - 3 } Model & Tolerance & \multicolumn{1}{c|}{ VIF } \\
\hline $1 \quad \begin{array}{c}\text { (Constant) } \\
\text { FoodConsumptiveLi } \\
\text { festyle }\end{array}$ & .467 & 2.142 \\
Income & .432 & 2.314 \\
Age & .869 & 1.151 \\
Education & .850 & 1.177 \\
& & \\
NumberofHousehol & .824 & 1.213 \\
dMembers & .813 & 1.230 \\
Drinking Jamu & .745 & 1.342 \\
FoodStock &
\end{tabular}

a. Dependent Variable: FoodExpenditure

The autocorrelation test is used to test whether the linear regression model is correlated between the confounding error in period $t$ and the disturbance error in the previous period $(\mathrm{t}-1)$. Based on the research results obtained:

$\mathrm{d}=1.940, \mathrm{~N}=62, \mathrm{du}=1.8472, \mathrm{dl}=1.3497$ 
If $\mathrm{dU} \leq \mathrm{d} \leq 4-\mathrm{dU} \rightarrow$ receive $\mathrm{H} 0$, Reject $\mathrm{H} 1$

This means there is no positive or negative autocorrelation.

Model Summaryb

\begin{tabular}{|c|c|c|c|c|c|}
\hline Model & $\mathrm{R}$ & $\begin{array}{c}\mathrm{R} \\
\text { Square }\end{array}$ & $\begin{array}{c}\text { Adjusted R } \\
\text { Square }\end{array}$ & $\begin{array}{c}\text { Std. Error of } \\
\text { the Estimate }\end{array}$ & $\begin{array}{c}\text { Durbin- } \\
\text { Watson }\end{array}$ \\
\hline 1 & $.684^{\mathrm{a}}$ & .468 & .399 & $3.51101 \mathrm{E} 5$ & 1.940 \\
\hline
\end{tabular}

a. Predictors: (Constant), Non-Food Stock, Non-Food Consumptive Lifestyle, Drinking Jamu, Age, Education, Number of House hold Members, Income

b. Dependent Variable: Non-food expenditure

Heteroskedasticity test is used to test whether in the regression model there is a variance inequality of the residual one observation to another observation. Based on the Scatterplot Image on the research result obtained Pattern is not systematic, therefore there is no heteroskedastisitas.

\section{Multiple Linear Regression Test Results:}

The results of multiple linear regression test begins by looking at the significance of $F$ (Unison) and t Test (partial).

$\mathrm{F}$ test (Simultaneous) is used to see whether simultaneously independent variables affect the dependent variable. Based on the result of research, $\mathrm{F}$ test result (Simultaneously) above, obtained Sig $=0.000$ and $\alpha=0.05(5 \%)$. If Sig $<\alpha$ Then $\mathrm{H} 1$ is accepted, $\mathrm{HO}$ is rejected, Thus it can be concluded that there is a real positive effect between Consumptive Lifestyle (food), Revenue, Age, Education, Number of Household, Drinking Herbal (traditional), Food stock simultaneously to Javanese Household Food Spending in Medan City.

ANOVA $^{b}$

\begin{tabular}{|c|c|c|c|c|c|c|}
\hline \multicolumn{2}{|c|}{ Model } & $\begin{array}{l}\text { Sum of } \\
\text { Square } \\
\text { S }\end{array}$ & Df & $\begin{array}{c}\text { Mean } \\
\text { Squar } \\
\text { e }\end{array}$ & $\mathrm{F}$ & Sig. \\
\hline 1 & $\begin{array}{l}\text { Regre } \\
\text { ssion }\end{array}$ & $\begin{array}{c}5.862 \mathrm{E} \\
12\end{array}$ & 7 & $\begin{array}{c}8.374 \\
\text { E11 }\end{array}$ & $\begin{array}{c}6.79 \\
3\end{array}$ & $.000^{a}$ \\
\hline & $\begin{array}{c}\text { Resid } \\
\text { ual }\end{array}$ & $\begin{array}{c}6.657 \mathrm{E} \\
12\end{array}$ & 54 & $\begin{array}{c}1.233 \\
\text { E11 }\end{array}$ & & \\
\hline & Total & $\begin{array}{c}1.252 \mathrm{E} \\
13\end{array}$ & 61 & & & \\
\hline
\end{tabular}

a. Predictors: (Constant), Non-Food Stock, Non-Food Consumptive Lifestyle, Drinking
Jamu, Age, Education, Number of House hold Members, Income

b. Dependent Variable: Non-food expenditure

t Test (partial) is used to see whether the partially independent variables affect the dependent variable. Based on the results of the study, it is known that the variable has Sig $<\alpha, \mathrm{H} 1$ is accepted, $\mathrm{HO}$ is rejected. And obtained explanation bahwasannya there is a real positive influence between income variables partially to the Consumption of Household Food Consumption Java in the City of Medan.

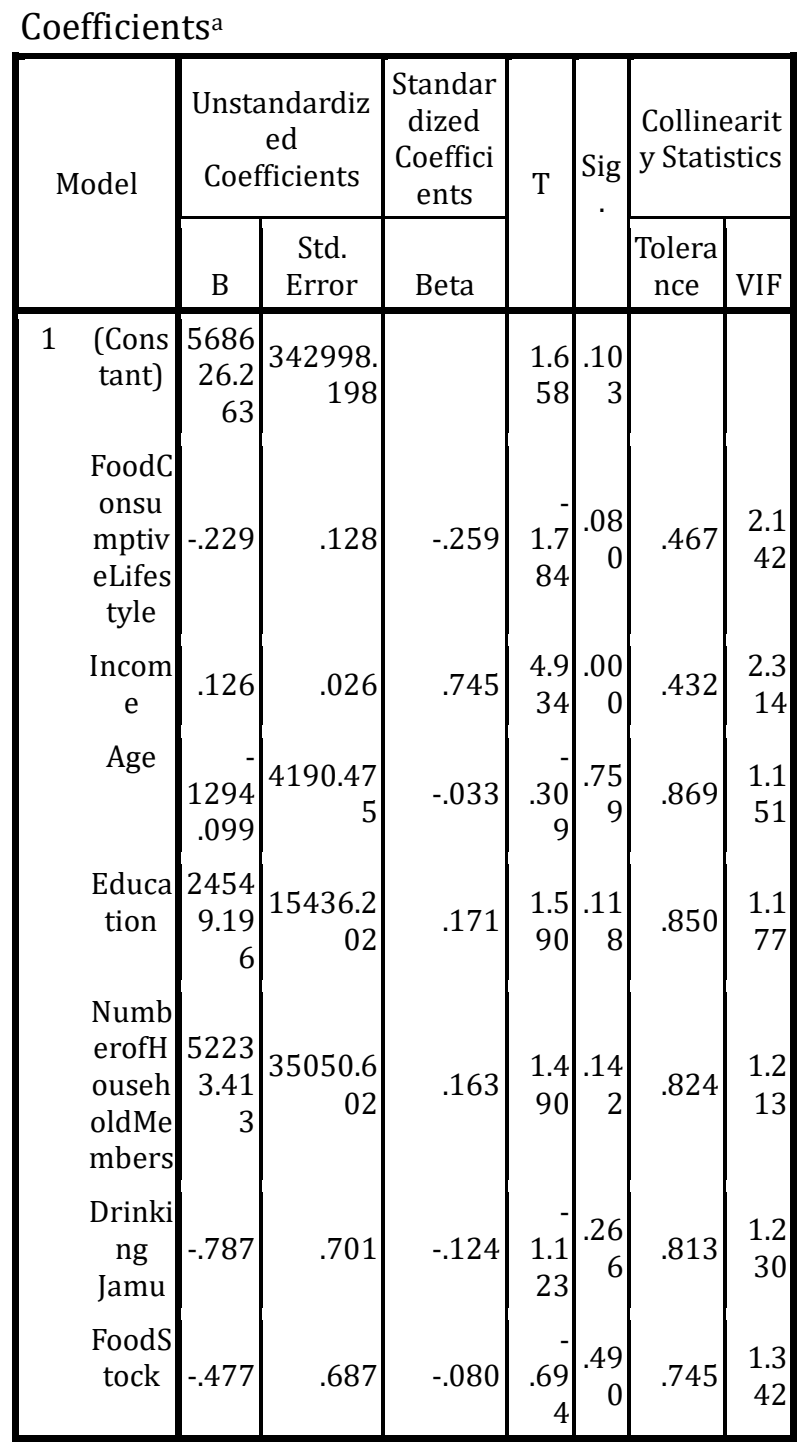

The influence of income on household food consumption expenditure of Java Tribe in Medan City has a significance value of 0.000 , meaning that if income increases then food consumption expenditure will also increase. This is 
consistent with Keynes's theory of consumption, which states that the level of consumption of a person or household is determined by his income. The higher the income then the higher the expenditure. The results of this study are in line with previous research by Agustin (2012).

\section{Factors Affecting Spending Batak Food Consumption in the City of Medan}

\section{Classic assumption test :}

Before the regression test to determine the factors that affect spending household food consumption Batak tribe in the city of Medan, first done Classic Assumption Test. The test that was made was Normality Test, Multicolinality Test, Autocorrelation Test, and Heteroscedasticity Test.

Normality test is used to detect whether the distribution of independent and bounded variables is normal. If sig $\geq \alpha$ Then $\mathrm{H} 0$ is accepted, $\mathrm{H} 1$ is rejected. The samples are normally distributed (Sig $=0.958>\alpha=0.05(5 \%)$ ).

\section{One-Sample Kolmogorov-Smirnov Test}

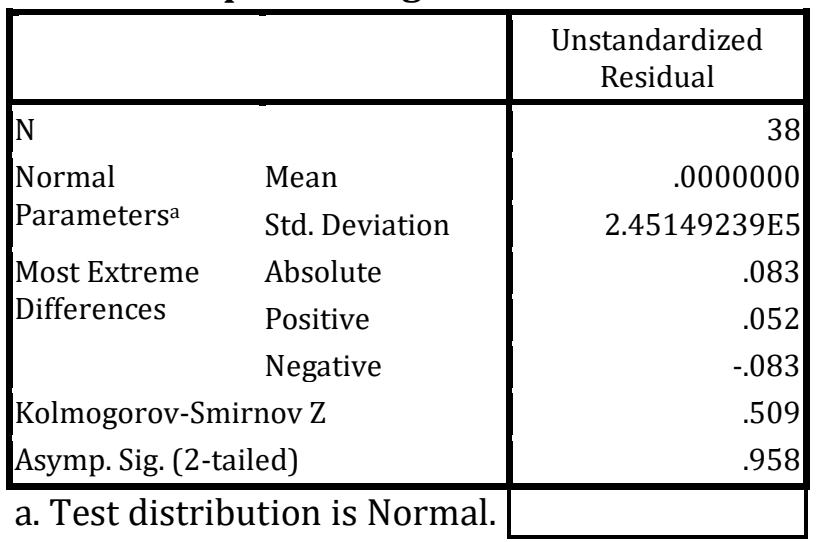

Multicolinearity test (tolerance> 0.1 and VIF $<10$ ) was used to test whether the regression model found correlation between independent variables. Based on the result of research, all variables have tolerance value $>0.1$ and VIF $<10$. Based on these criteria, the regression model is good because there is no correlation between the independent variables (Consumtive Lifestyle (food), Income, Age, Education, Number of Household Members, Eat sirih and Tuak (traditional)) and Food Stock.

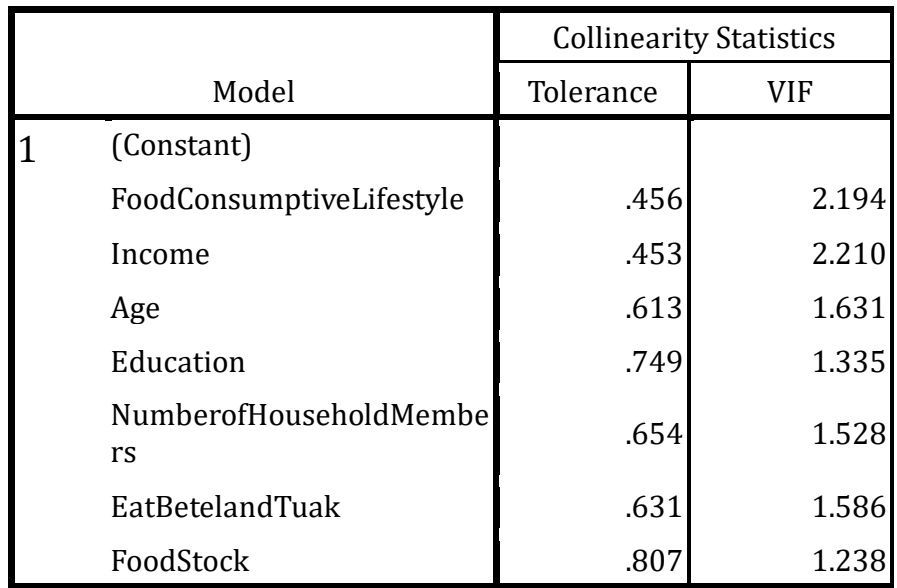

a. Dependent Variable: Food Expenditure

The autocorrelation test is used to test whether the linear regression model is correlated between the confounding error in period $t$ and the disturbance error in the previous period ( $t-1)$. Based on the results of research, obtained value $\mathrm{d}=$ 2.277, $\mathrm{N}=38, \mathrm{du}=1.9394, \mathrm{dl}=1.0879$

If $4-\mathrm{dU} \leq \mathrm{d} \leq 4-\mathrm{dL} \rightarrow$ we can not take any conclusions

Model Summaryb

\begin{tabular}{|l|l|l|l|l|l|}
\hline Model & $\mathrm{R}$ & $\begin{array}{l}\mathrm{R} \\
\text { Square }\end{array}$ & $\begin{array}{l}\text { Adjusted } \\
\text { R Square }\end{array}$ & $\begin{array}{l}\text { Std. Error of } \\
\text { the Estimate }\end{array}$ & $\begin{array}{l}\text { Durbin- } \\
\text { Watson }\end{array}$ \\
\hline 1 & $.784^{\mathrm{a}}$ & .615 & .525 & $2.72252 \mathrm{E} 5$ & 2.277 \\
\hline
\end{tabular}

c. Predictors: (Constant), Non-Food Stock, Non-Food Consumptive Lifestyle, Drinking Jamu, Age, Education, Number of House hold Members, Income

d. Dependent Variable: Non-food expenditure

Heteroskedasticity test is used to test whether in the regression model there is a variance inequality of the residual one observation to another observation. Based on the Scatterplot Image on the results of research, obtained Pattern is not systematic, therefore there is no heteroscedasticity.

\section{Multiple Linear Regression Test Results:}

The results of multiple linear regression test begins by looking at the significance of $F$ (Unison) and Test $t$ (partial).

$\mathrm{F}$ test (Simultaneous) is used to see whether simultaneously independent variables affect the dependent variable. Based on the result of research, $\mathrm{F}$ test result (Simultaneously) above, obtained Sig $=0.000$ and $\alpha=0.05(5 \%)$. If Sig $<\alpha$ 
Then $\mathrm{H} 1$ is accepted, $\mathrm{H} 0$ is rejected, Thus it can be concluded that there is a real positive effect between Consumptive Lifestyle (food), Revenue, Age, Education, Household Amount, Sirih and Tuak (traditional) and food stocks simultaneously on Household Food Spending in Batak City.

ANOVA $^{b}$

\begin{tabular}{|c|c|c|c|c|c|}
\hline Model & $\begin{array}{c}\text { Sum of } \\
\text { Squares }\end{array}$ & Df & $\begin{array}{c}\text { Mean } \\
\text { Square }\end{array}$ & F & Sig. \\
\hline 1 Regression & $3.549 \mathrm{E} 12$ & 7 & $5.070 \mathrm{E} 11$ & 6.841 & $.000^{\mathrm{a}}$ \\
Residual & $2.224 \mathrm{E} 12$ & 30 & $7.412 \mathrm{E} 10$ & & \\
Total & $5.773 \mathrm{E} 12$ & 37 & & & \\
\hline
\end{tabular}

a. Predictors: (Constant), Non-Food Stock, Non-Food Consumptive Lifestyle, Drinking Jamu, Age, Education, Number of House hold Members, Income

b. Dependent Variable: Non-food expenditure c.

Test $t$ (Partial) is used to see whether the partially independent variables affect the dependent variable. Based on the results of the study, it is known that the variable has Sig $<\alpha, \mathrm{H} 1$ is accepted, $\mathrm{HO}$ is rejected. And there is an explanation that there is a real positive effect between lifestyle consumptive variable of food, income, and age partially to Batak Food Consumption Expenditure of Batak Tribe in Medan City.

\begin{tabular}{|c|c|c|c|c|c|c|c|}
\hline \multirow[b]{2}{*}{ Model } & \multicolumn{2}{|c|}{$\begin{array}{l}\text { Unstandardized } \\
\text { Coefficients }\end{array}$} & \multirow{2}{*}{$\begin{array}{c}\begin{array}{c}\text { Standar } \\
\text { dized } \\
\text { Coefficie } \\
\text { nts }\end{array} \\
\\
\text { Beta }\end{array}$} & \multirow[b]{2}{*}{$\mathrm{T}$} & \multirow[b]{2}{*}{ Sig. } & \multicolumn{2}{|c|}{$\begin{array}{c}\text { Collinearity } \\
\text { Statistics }\end{array}$} \\
\hline & B & $\begin{array}{l}\text { Std. } \\
\text { Error }\end{array}$ & & & & $\begin{array}{c}\text { Tolera } \\
\text { nce }\end{array}$ & VIF \\
\hline 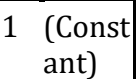 & $\begin{array}{r}85977 \\
1.277\end{array}$ & $\begin{array}{r}32263 \\
8.338\end{array}$ & & $\begin{array}{r}2.66 \\
5\end{array}$ & .012 & & \\
\hline $\begin{array}{l}\text { FoodC } \\
\text { onsu } \\
\text { mptiv } \\
\text { eLifes } \\
\text { tyle }\end{array}$ & .238 & .105 & .381 & $\begin{array}{r}2.27 \\
0\end{array}$ & .031 & .456 & $\begin{array}{r}2.19 \\
4\end{array}$ \\
\hline $\begin{array}{l}\text { Incom } \\
\mathrm{e}\end{array}$ & .044 & .021 & .356 & $\begin{array}{r}2.11 \\
6\end{array}$ & .043 & .453 & $\begin{array}{r}2.21 \\
0\end{array}$ \\
\hline Age & $\begin{array}{r}12399 . \\
610\end{array}$ & $\begin{array}{r}4875.4 \\
82\end{array}$ & .368 & $\begin{array}{r}2.54 \\
3\end{array}$ & .016 & .613 & $\begin{array}{r}1.63 \\
1\end{array}$ \\
\hline $\begin{array}{l}\text { Educa } \\
\text { tion }\end{array}$ & $\begin{array}{r}- \\
9921.6 \\
47\end{array}$ & $\begin{array}{r}19224 . \\
438\end{array}$ & -.068 & -.516 & .610 & .749 & $\begin{array}{r}1.33 \\
5\end{array}$ \\
\hline
\end{tabular}

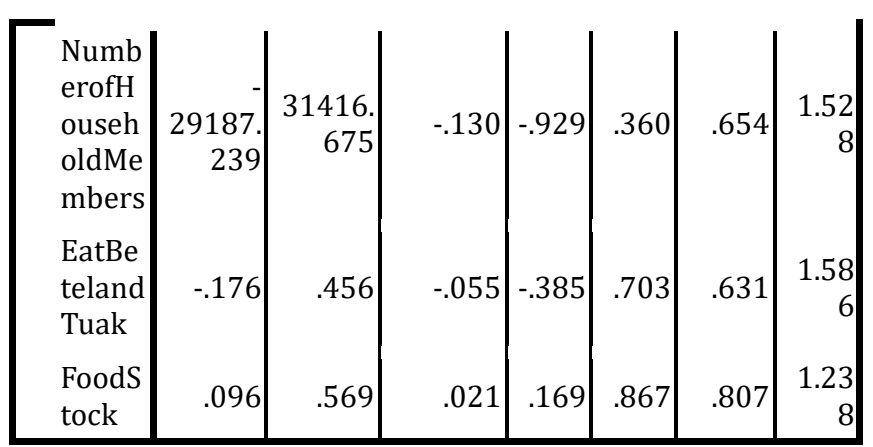

a. Predictors: (Constant), Non-Food Stock, Non-Food Consumptive Lifestyle, Drinking Jamu, Age, Education, Number of House hold Members, Income

Effect of consumptive lifestyle of household food of Batak Tribe in Medan City has significance value equal to 0,031 , meaning if consumptive lifestyle of household food increases then food consumption expenditure will also increase. This is in accordance with Kotler's theory, that there are lifestyle factors that influence consumer behavior.

The influence of income on household food consumption expenditure of Batak Tribe in Medan City has a significance value of 0.043 , meaning that if income increases then food consumption expenditure will also increase. According to Keynes's theory of consumption, the consumption level of a person or household is determined by his income. And also supported from previous research by Nurhikmah (2009).

The influence of age to household food consumption expenditure of Batak Tribe in Medan City has a significance value of 0.016 , meaning that if age increases then food consumption expenditure will also increase. This is in accordance with previous research review by Noni (2013).

\section{Factors Affecting Non-Food Household Consumption Spending on Java Tribe in Medan City}

\section{Classic assumption test :}

Before the regression test to determine the factors that affect the consumption of non-food household consumption of Java Tribe in Medan City, first done Classic Assumption Test. The test that was made was Normality Test, Multicolinality Test, Autocorrelation Test, and Heteroscedasticity Test.

Normality test is used to detect whether 
the distribution of independent and bounded variables is normal. If sig $\geq \alpha$ Then $\mathrm{H} 0$ is accepted, $\mathrm{H} 1$ is rejected. The samples are normally distributed ( $\operatorname{Sig}=0.168>\alpha=0.05(5 \%)$ ).

One-Sample Kolmogorov-Smirnov Test

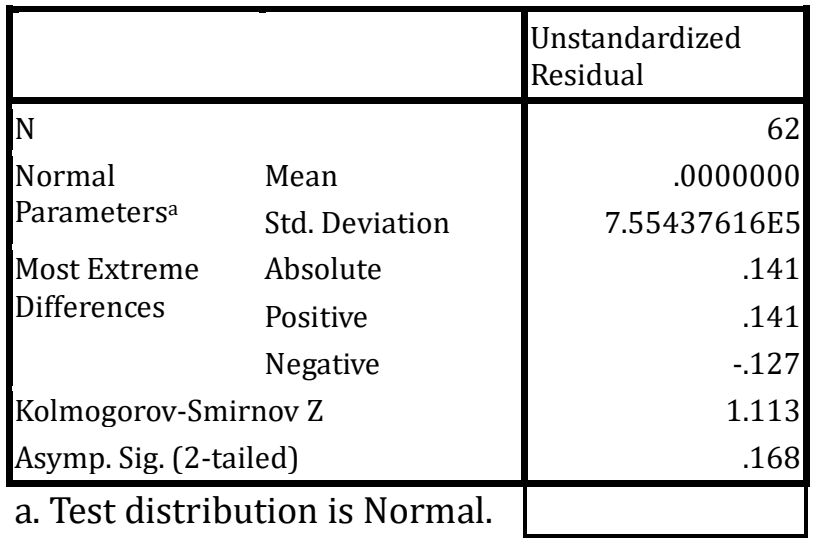

Multicolinearity test (tolerance> 0.1 and VIF <10) was used to test whether the regression model found a correlation between independent variables. Based on the result of research, all variables have tolerance value $>0.1$ and VIF $<10$. Based on these criteria, the regression model is good because there is no correlation between the independent variables (Consumtive Lifestyle (Nonfood), Income, Age, Education, Number of Household Members, Traditional Drinking), and non-food stock.

\begin{tabular}{|c|c|c|c|}
\hline & \multirow[b]{2}{*}{ Model } & \multicolumn{2}{|c|}{ Collinearity Statistics } \\
\hline & & Tolerance & VIF \\
\hline \multirow[t]{8}{*}{1} & (Constant) & & \\
\hline & $\begin{array}{l}\text { Non- } \\
\text { FoodConsumptiveLifesty } \\
\text { le }\end{array}$ & .847 & 1.180 \\
\hline & Income & .638 & 1.568 \\
\hline & Age & .839 & 1.192 \\
\hline & Education & .828 & 1.208 \\
\hline & $\begin{array}{l}\text { NumberofHouseholdMe } \\
\text { mbers }\end{array}$ & .763 & 1.310 \\
\hline & Drinking Jamu & .945 & 1.058 \\
\hline & Non-FoodStock & .736 & 1.358 \\
\hline
\end{tabular}

a. Dependent Variable: Non-foodexpenditure

The autocorrelation test is used to test whether the linear regression model is correlated between the confounding error in period $t$ and the disturbance error in the previous period $(t-1)$.
Based on result of research, obtained value $\mathrm{d}=$ $1.604, \mathrm{~N}=62, \mathrm{du}=1.8472, \mathrm{dl}=1.3497$

If $\mathrm{dL} \leq \mathrm{d} \leq \mathrm{dU} \rightarrow$ we can not take any conclusions

Model Summaryb

\begin{tabular}{|l|l|l|l|l|l|}
\hline Model & $\mathrm{R}$ & R Square & $\begin{array}{c}\text { Adjusted R } \\
\text { Square }\end{array}$ & $\begin{array}{c}\text { Std. Error } \\
\text { of the } \\
\text { Estimate }\end{array}$ & $\begin{array}{l}\text { Durbin- } \\
\text { Watson }\end{array}$ \\
\hline 1 & $.619 \mathrm{a}$ & .383 & .304 & $8.02910 \mathrm{E} 5$ & 1.604 \\
\hline
\end{tabular}

a. Predictors: (Constant), Non-Food Stock, Non-Food Consumptive Lifestyle, Drinking Jamu, Age, Education, Number of House hold Members, Income

b. Dependent Variable: Non-food expenditure

Heteroskedasticity test is used to test whether in the regression model there is a variance inequality of the residual one observation to another observation. Based on the Scatterplot Image on the results of research, obtained Pattern is not systematic, therefore there is no heteroscedasticity.

\section{Multiple Linear Regression Test Results:}

The results of multiple linear regression test begins by looking at the significance of $\mathrm{F}$ (Unison) and Test t (partial).

$\mathrm{F}$ test (Simultaneous) is used to see whether simultaneously independent variables affect the dependent variable. Based on the result of research, $F$ test (Simultaneously) above, obtained Sig $=0.000$ and $\alpha=0.05$ (5\%). If Sig $<\alpha$ Then H1 is accepted, H0 is rejected, Thus it can be concluded that there is a real positive effect between the Consumer (Non-food) Lifestyle, Income, Age, Education, Number of Household, Drinking Herbal (Traditional) non-food simultaneously to Non-Food Household Food Spending in Medan City. 
ANOVA $^{\mathrm{b}}$

\begin{tabular}{|cc|c|c|c|c|c|}
\hline \multicolumn{1}{|c|}{ Model } & $\begin{array}{c}\text { Sum of } \\
\text { Squares }\end{array}$ & Df & $\begin{array}{c}\text { Mean } \\
\text { Square }\end{array}$ & $\mathrm{F}$ & Sig. \\
\hline 1 & Regression & $2.165 \mathrm{E} 13$ & 7 & $\begin{array}{c}3.093 \mathrm{E} 1 \\
2\end{array}$ & 4.798 & $.000^{\mathrm{a}}$ \\
& & & & \\
& Residual & $3.481 \mathrm{E} 13$ & 54 & $\begin{array}{c}6.447 \mathrm{E} 1 \\
1\end{array}$ & & \\
& & & & & \\
& Total & $5.646 \mathrm{E} 13$ & 61 & & & \\
\hline
\end{tabular}

a. Predictors: (Constant), Non-Food Stock, Non-Food Consumptive Lifestyle, Drinking Jamu, Age, Education, Number of House hold Members, Income

b. Dependent Variable: Non-food expenditure

Test $t$ (Partial) is used to see whether the partially independent variables affect the dependent variable. Based on the results of the study, it is known that the variable has Sig $<\alpha, \mathrm{H} 1$ is accepted, $\mathrm{HO}$ is rejected. And obtained explanation bahwasannya there is a real positive effect between income variables partially to Non-Food Consumption Food Household Java in the City of Medan.

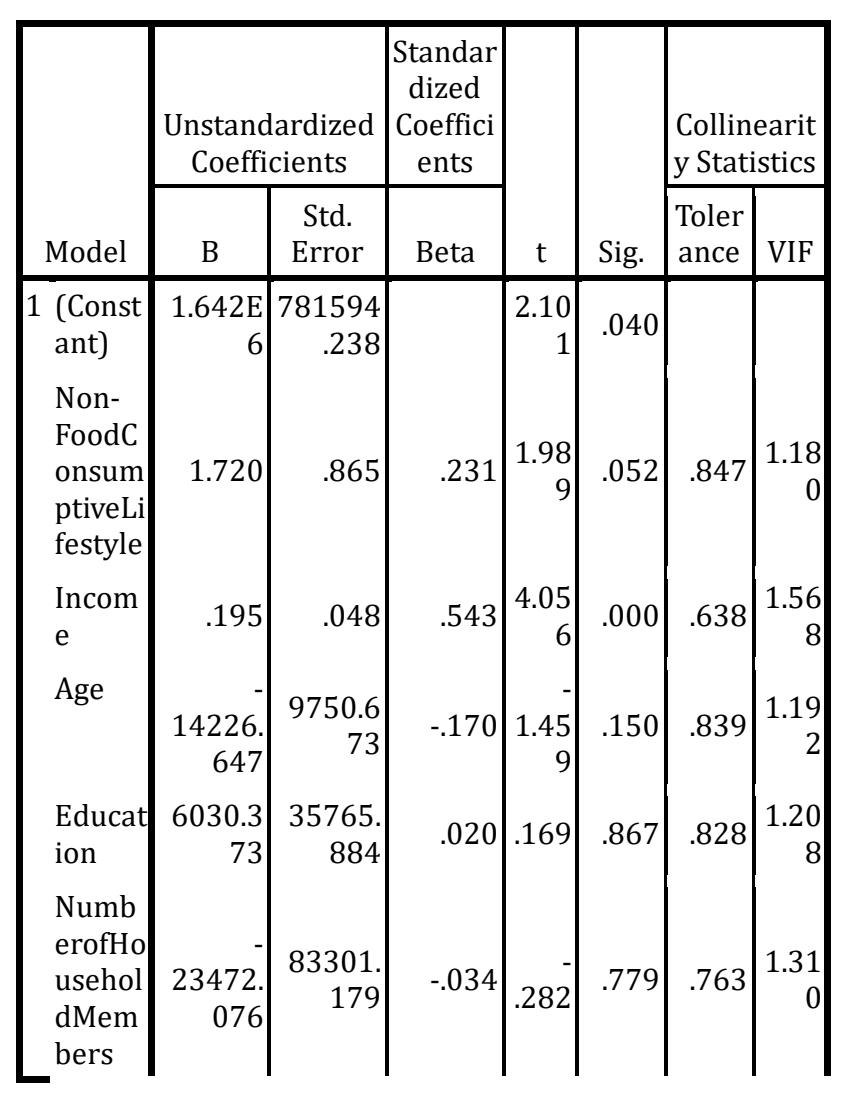

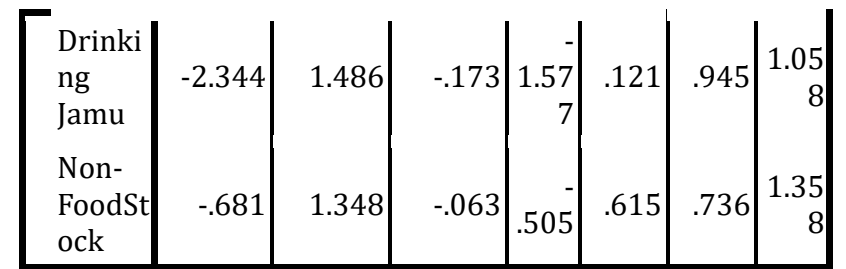

a. Dependent Variable: Non-foodexpenditure

The influence of income on non-food consumption expenditure of Javanese households in Medan City has a significance value of 0.000 , meaning that if income increases then non-food consumption expenditure will also increase. This is consistent with Keynes's theory of consumption, stating that the level of consumption of a person or household is determined by his income. The higher the income, the higher the level of consumption.

\section{Factors Affecting Non-Food Consumption Spending on Batak Households in Medan City}

\section{Classic assumption test :}

Before the regression test to determine the factors that affect the non-food consumption of household consumption of Batak tribe in the city of Medan, first done Classic Assumption Test. The test that was made was Normality Test, Multicolinality Test, Autocorrelation Test, and Heteroscedasticity Test.

Normality test is used to detect whether the distribution of independent and bounded variables is normal. If sig $\geq \alpha$ Then $\mathrm{HO}$ is accepted, $\mathrm{H} 1$ is rejected. The samples are normally distributed (Sig $=0.742>\alpha=0.05(5 \%)$ ).

\section{One-Sample Kolmogorov-Smirnov Test}

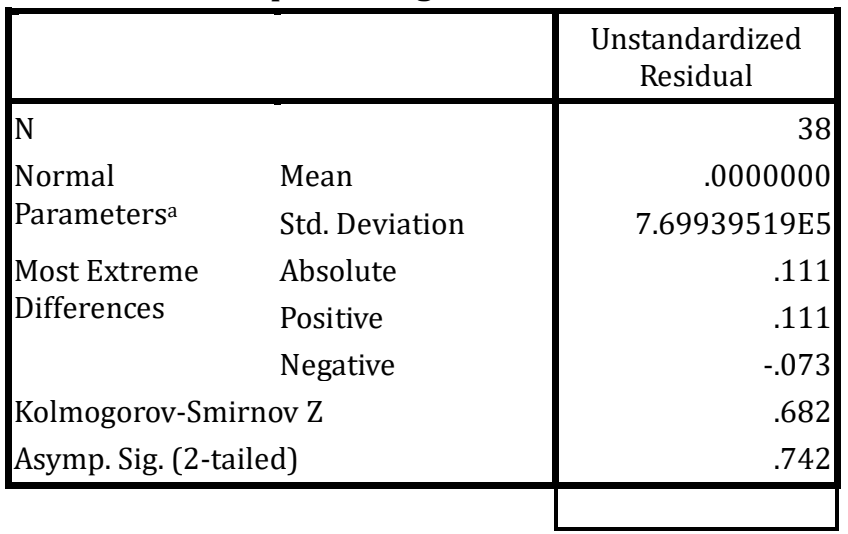

a. Test distribution is Normal.

Multicolinearity test (tolerance> 0.1 and VIF $<10$ ) was used to test whether the regression 
model found a correlation between independent variables. Based on the result of research, all variables have tolerance value $>0.1$ and VIF $<10$. Based on these criteria, the regression model is good because there is no correlation between the independent variables (Consumtive Lifestyle (nonfood), Income, Age, Education, Number of Household Members, Eat sirih and Tuak (traditional)) and Non-Food Stock.

\begin{tabular}{|ll|r|r|}
\hline \multirow{2}{*}{\multicolumn{1}{|c|}{ Model }} & \multicolumn{2}{c|}{ Collinearity Statistics } \\
\cline { 2 - 3 } & \multicolumn{1}{c|}{ Tolerance } & \multicolumn{1}{c|}{ VIF } \\
\hline $1 \quad$ (Constant) & & \\
& Non- & \\
FoodConsumptiveLifest & .647 & 1.547 \\
yle & & \\
Income & .753 & 1.328 \\
Age & .560 & 1.787 \\
Education & .712 & 1.404 \\
NumberofHouseholdMe & .730 & 1.370 \\
mbers & .658 & 1.519 \\
EatBetelandTuak & .794 & 1.259 \\
Non-FoodStock & & \\
\hline
\end{tabular}

a. Dependent Variable: Non-foodexpenditure

The autocorrelation test is used to test whether the linear regression model is correlated between the confounding error in period $t$ and the disturbance error in the previous period (t-1). Based on the results of research, obtained value $d=$ $1.743, \mathrm{~N}=38, \mathrm{du}=1.9394, \mathrm{dl}=1.0879$

If $\mathrm{dL} \leq \mathrm{d} \leq \mathrm{dU} \rightarrow$ we can not take any conclusions

\begin{tabular}{|c|c|c|c|c|c|}
\hline Model & $\mathrm{R}$ & $\begin{array}{c}\mathrm{R} \\
\text { Square }\end{array}$ & $\begin{array}{c}\text { Adjusted } \\
\mathrm{R} \\
\text { Square }\end{array}$ & $\begin{array}{c}\text { Std. } \\
\text { Error of } \\
\text { the } \\
\text { Estimate }\end{array}$ & $\begin{array}{l}\text { Durbin- } \\
\text { Watson }\end{array}$ \\
\hline 1 & $.493 \mathrm{a}$ & .243 & .067 & $\begin{array}{c}8.55061 \\
\mathrm{E} 5\end{array}$ & 1.743 \\
\hline
\end{tabular}

a. Predictors: (Constant), Non-Food Stock, Non-Food Consumptive Lifestyle, Drinking Jamu, Age, Education, Number of House hold Members, Income

b. Dependent Variable: Non-food expenditure

Heteroskedasticity test is used to test whether in the regression model there is a variance inequality of the residual one observation to another observation. Based on the Scatterplot Image on the results of research, Provided Pattern is not systematic, therefore there is no heteroskedastisitas.

\section{Multiple Linear Regression Test Results:}

The results of multiple linear regression test begins by looking at the significance of $\mathrm{F}$ (Unison) and Test t (partial).

$\mathrm{F}$ test (Simultaneous) is used to see whether simultaneously independent variables affect the dependent variable. Based on the result of research, $\mathrm{F}$ test result (Simultaneously) above, obtained Sig $=0.250$ and $\alpha=0.05$ (5\%). If Sig> $\alpha$ Then H0 is accepted, H1 is rejected. Thus there can be concluded that there is no real positive effect between the variables of Consumtive Lifestyle (Non-food), Income, Age, Education, Number of Household Members, Eat Betel and Tuak (Traditional), and Non-Food Stocks simultaneously to Non Spending Batak Household Food in Medan City.

\section{ANOVA $^{b}$}

\begin{tabular}{|ll|c|c|c|c|c|}
\hline \multicolumn{1}{|c|}{ Model } & $\begin{array}{c}\text { Sum of } \\
\text { Squares }\end{array}$ & Df & $\begin{array}{c}\text { Mean } \\
\text { Square }\end{array}$ & F & Sig. \\
\hline 1 & Regression & $7.056 \mathrm{E} 12$ & 7 & $1.008 \mathrm{E}$ & 1.3 & $.250 \mathrm{a}$ \\
12 & 79 & .25 \\
& & & & $7.311 \mathrm{E}$ & & \\
& Residual & $2.193 \mathrm{E} 13$ & 30 & & \\
& & & & & \\
& Total & $2.899 \mathrm{E} 13$ & 37 & & & \\
\hline
\end{tabular}

a. Predictors: (Constant), Non-Food Stock, Non-Food Consumptive Lifestyle, Drinking Jamu, Age, Education, Number of House hold Members, Income

b. Dependent Variable: Non-food expenditure

Test $t$ (Partial) is used to see whether the partially independent variables affect the dependent variable. Based on the results of the study, it is known that the variable has Sig $<\alpha, \mathrm{H} 1$ is accepted, $\mathrm{HO}$ is rejected. And obtained explanation bahwasannya there is a real positive effect between the variable number of household members partially to Non-Food Consumption Spending Batak Households in the city of Medan. 


\section{Coeficients}

\begin{tabular}{|c|c|c|c|c|c|c|c|}
\hline \multirow[b]{2}{*}{ Model } & \multicolumn{2}{|c|}{$\begin{array}{c}\text { Unstandardi } \\
\text { zed } \\
\text { Coefficients }\end{array}$} & \multirow{2}{*}{ 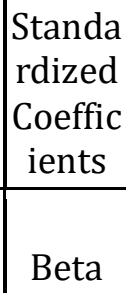 } & \multirow[b]{2}{*}{$\mathrm{t}$} & \multirow[b]{2}{*}{ Sig. } & \multicolumn{2}{|c|}{$\begin{array}{l}\text { Collinearity } \\
\text { Statistics }\end{array}$} \\
\hline & B & $\begin{array}{c}\text { Std. } \\
\text { Error }\end{array}$ & & & & $\begin{array}{l}\text { Toler } \\
\text { ance }\end{array}$ & VIF \\
\hline $\begin{array}{c}1 \text { (Cons } \\
\text { tant) } \\
\text { Non- } \\
\text { Food } \\
\text { Cons } \\
\text { umpti } \\
\text { veLife } \\
\text { style }\end{array}$ & $\begin{array}{r}9098 \\
19.65 \\
4\end{array}$ & $\begin{array}{r}1.042 \\
\text { E6 }\end{array}$ & -.098 & $\begin{array}{r}.87 \\
3\end{array}$ & $\begin{array}{r}.62 \\
2\end{array}$ & .647 & $\begin{array}{r}1.54 \\
7\end{array}$ \\
\hline $\begin{array}{l}\text { Inco } \\
\text { me }\end{array}$ & .082 & .051 & .294 & $\begin{array}{r}1.6 \\
06\end{array}$ & $\begin{array}{r}.11 \\
9\end{array}$ & .753 & $\begin{array}{r}1.32 \\
8\end{array}$ \\
\hline Age & $\begin{array}{r}- \\
1616 \\
9.811\end{array}$ & $\begin{array}{r}1602 \\
8.155\end{array}$ & -.214 & $\begin{array}{r}1.0 \\
09\end{array}$ & $\begin{array}{r}.32 \\
1\end{array}$ & .560 & $\begin{array}{r}1.78 \\
7\end{array}$ \\
\hline $\begin{array}{l}\text { Educ } \\
\text { ation }\end{array}$ & $\begin{array}{r}- \\
1625 \\
1.493\end{array}$ & $\begin{array}{r}6191 \\
6.475\end{array}$ & -.049 & $\begin{array}{r}- \\
.26 \\
2\end{array}$ & $\begin{array}{r}.79 \\
5\end{array}$ & .712 & $\begin{array}{r}1.40 \\
4\end{array}$ \\
\hline $\begin{array}{l}\text { Num } \\
\text { berof } \\
\text { Hous } \\
\text { ehold } \\
\text { Mem } \\
\text { bers }\end{array}$ & $\begin{array}{r}2365 \\
87.67 \\
8\end{array}$ & $\begin{array}{r}9341 \\
5.495\end{array}$ & .471 & $\begin{array}{r}2.5 \\
33\end{array}$ & $\begin{array}{r}.01 \\
7\end{array}$ & .730 & $\begin{array}{r}1.37 \\
0\end{array}$ \\
\hline $\begin{array}{l}\text { EatBe } \\
\text { telan } \\
\text { dTua } \\
\mathrm{k}\end{array}$ & 1.348 & 1.403 & .188 & $\begin{array}{r}.96 \\
1\end{array}$ & $\begin{array}{r}.34 \\
4\end{array}$ & 658 & $\begin{array}{r}1.51 \\
9\end{array}$ \\
\hline $\begin{array}{l}\text { Non- } \\
\text { Food } \\
\text { Stock }\end{array}$ & 1.731 & 4.862 & .063 & $\begin{array}{r}.35 \\
6\end{array}$ & $\begin{array}{r}.72 \\
4\end{array}$ & .794 & $\begin{array}{r}1.25 \\
9\end{array}$ \\
\hline
\end{tabular}

a. Dependent Variable: Non-foodexpenditure

The influence of the number of household members to household consumption expenditure of Batak Tribe in Medan City has a significance value of 0.017 , meaning that if the number of household members increases then non-food consumption expenditure will also increase. Modigliani Consumption Theory assumes that the amount of consumption, should not depend on the basis of income. Because in essence the income itself varies greatly, that is, when a person can still manage his income from savings when income is low, high, or no income eg due to pension that has been paid upfront, and so forth. Modigliani consumption theory is called the Life Cycle Hypothesis. This theory explains that the amount of consumption depends not only on the amount of income, but also on the amount of wealth owned, where this wealth can be generated through savings, investment, income allowance, inheritance, and so forth.

\section{CONCLUSIONS AND SUGGESTIONS Conclusion}

Based on the results of research and discussion that has been discussed, it can be drawn conclusions as follows:

1. Consumption expenditure Java is dominated by non-food consumption expenditure, while Batak consumption expenditure is dominated by food consumption expenditure. For type of Java Food expenditure more dominant to the expenditure of sugar and beans. While the type of Batak Food expenditure is more dominant to the expenditure of oil and fat, and nuts. For the type of non-food expenditure Java Tribe is more dominant to the expenditures for the purpose of buying the needs of Idul Fitri holidays. While the type of non-food expenditure Batak Tribe more dominant to the expenditure for the purposes of the party and ceremony.

2. Factors that affect food consumption expenditure The Javanese is the income factor. While the factors that affect food consumption expenditure Batak tribe is a factor Consumtive Lifestyle Food, Income, and Age.

3. Factors affecting non-food consumption expenditure Java Tribe in Medan City is income factor, while the factors that influence non-food consumption expenditure Batak tribe in Medan City is the factor of the number of household members. 


\section{SUGGESTION}

From the analysis that has been obtained, the author would like to submit some suggestions as follows:

1. To the Government, it is expected to anticipate the provision of food reserves that the community needs if there is an increase in the income of the community through a more careful economic planning program.

2. To the Government, it is expected to encourage Family Planning program to reduce consumption expenditure and to the community, it is expected to participate in family planning program.

3. To the next researcher relating to household consumption, it is expected to use various other variables, such as savings to be more varied and other causality methods so that obtained more perfect results and can complement this research.

\section{BIBLIOGRAPHY}

Agustin, Niken. 2012. Analysis of Household Consumption of Rice and Coastal Farmers in Demak District. Semarang. Diponegoro University.

Central Bureau of Statistics Medan. 2016.

Gilarso, T. 1992. Introduction to Macro Economics Section. Kanisius. Yogyakarta.

Huda, Mifta. 2012. http://huda57.blogspot.co.id/. Retrieved On March 18, 2017. At 11:25 hrs.

Kotler and Keller, 2012. Marketing Management. Issue 14. Global Edition. Pearson Prentice Hall.

Mangkoesoebroto, Guritno. 2001. Public Economy. Issue 3. FE UGM. Yogyakarta.

Mankiw. 2006. Macro Economics. PT Gelora Aksara Pratama. Jakarta.

Nainggolan, Pahala. 2015. http://nyakku.blogspot.co.id/2015/02/batak-itubanyak-makan-biar-sehat.html. Retrieved Date 05 August 2017 At 10:03 pm.

Nazir, Mohd. 2005. Research Methods. Ghalia
Indonesia. Jakarta.

Nicholson, W. 2001. Intermediate Microeconomics and Its Applications. Eighth Edition. Erland. Jakarta.

Noni, et al. 2013. Factors that affect the consumption of animal food to household consumers in the city of Padang. Journal of Community Agribusiness, Volume 3, No. 1, November.

Nurhikmah. 2009. Analysis of Factors Affecting Household Consumption Expenditure "Kelurahan Aek Kota Batu, KecamatanNAIX-X, Labuhan Batu Utara". Field. University of Northern Sumatra.

Reksoprayitno, Soediyono. 2000. Macroeconomics. BPFE. Yogyakarta.

Samuelson and Nordhaus. 1995. Macroeconomics. Global Media Education. Jakarta.

Population Census Medan City. 2010.

Sugiono. 2012. Qualitative Quantitative Research Methods and R \& D. Alfabeta. Bandung.

Suparmoko. 1991. Introduction to Macro Economics. BPFE. Yogyakarta. 